\title{
Achieving Sustainability in Commercial Buildings in Nigeria: The FM Approach
}

\author{
Olaniyi Olayinka ${ }^{1}$, Smith Andrew ${ }^{2}$ \\ ${ }^{1}$ Department of Quantity Surveying, School of Environmental Studies Yaba, College of Technology, Lagos, Nigeria \\ ${ }^{2}$ School of Engineering and the Built Environment, Edinburgh Napier University, Edinburgh, Scotland \\ Email address: \\ yinka2k1@yahoo.com (O. Olayinka),a.smith7@napier.ac.uk (S. Andrew)
}

\section{To cite this article:}

Olaniyi Olayinka, Smith Andrew. Achieving Sustainability in Commercial Buildings in Nigeria: The FM Approach. Journal of Civil, Construction and Environmental Engineering. Vol. 3, No. 1, 2018, pp. 1-4. doi: 10.11648/j.jccee.20180301.11

Received: November 23, 2017; Accepted: December 4, 2017; Published: January 17, 2018

\begin{abstract}
People around the world are beginning to aspire to live and work in sustainable buildings (SBs), that is, buildings that are comfortable, healthy and have low impact on the environment. However, many buildings in Nigeria, particularly commercial buildings, are far from being comfortable and healthy. Many are in a state of deterioration due to poor design, unsustainable construction practices and mismanagement. Nigeria has a history of unsustainable building practices, mismanagement of buildings and poor maintenance culture with no consideration for its impact on the environment. FM is viewed as a practice, process and profession that can promote sustainability in Nigerian buildings. The purpose of this study is to determine the extent of sustainable facilities management (FM) practice in the management of commercial buildings in Nigeria and identify barriers to it, in order to develop a solution model that will proffer ways of overcoming these barriers and ultimately determine sustainable methods by which facility managers in Nigeria can effectively manage commercial properties. The study reviews FM functions in relation to BREEAM-NC UK, LEED-NC US, ISO Sustainability in Building Construction and BS Building Regulation PD 6501: Part 3: 1985 in order to identify sustainable FM functions in buildings. There is a need to investigate sustainable FM practice in the management of commercial buildings in Nigeria as commercial buildings are the economic powerhouse of the nation, serving the whole of the country in respect of imports and locally manufactured goods; and contributing more than $70 \%$ of the national economic output. This study is a work in progress and it presents a theoretical review on the extent of sustainable FM in developed countries, especially the United Kingdom (UK), and comparing it with the development of sustainable FM in developing countries and Nigeria in particular. The findings so far, identify commitment of senior management personnel, as a major driver to the course of sustainable FM and the three main barriers to sustainable FM practice in corporate organisations, as lack of training and tools, lack of relevant laws and regulation, and lack of knowledge and awareness. Nevertheless, there remains the urgent need to investigate barriers of sustainable FM practice in the management of commercial buildings in Nigeria.
\end{abstract}

Keywords: Sustainability, Sustainable Facilities Management, Nigeria

\section{Introduction}

Sustainable development has been defined as "development that meets the needs of the present without compromising the ability of future generations to meet their own needs" [1]. Sustainability is about leaving the environment in at least the same state by a generation and leaving it in a better state for newer generations to come [2]. It is the creation and maintenance of environments under which man and nature coexist [3].

The race towards sustainability has shown the role of buildings as an agent of decay on the natural environment, bringing fresh challenges for building engineers to devise new ways of reducing the use of natural resources, making use of renewable materials and minimising waste. This has created the need for sustainable FM, which has been seen to be vital in the longest phase of the life-cycle of a building, where severe impact on the environment occurs $[4,5,6]$.

Buildings are the main physical assets of any nation; they are created for providing shelter and enhancing people's quality of life [7]. If these buildings are not properly planned and maintained, they will become liabilities [8]. In the UK, from the year $2002,50 \%$ of all annual construction activities 
were exclusively for building maintenance [7]. However, this is not the case in Nigeria, where there is poor maintenance culture and values, resulting in deteriorations and eventual defects of various degrees $[9,10]$. Commercial buildings in Nigeria have a record of poor performance operations, poor maintenance and mismanagement [11]. In the past two decades, the emphasis has been on the development of new infrastructure and properties, with little attention paid to the maintenance of the existing stock and the future maintenance needs of the proposed ones $[12,13]$. These problems form the basis of this study. This paper argues that an integration of sustainable FM practice is required to promote the development and preservation of sustainable buildings with suitable environmental initiatives and practices within Nigeria.

\section{Sustainable FM in Sustainable Building}

This phase of the research study reviews existing literature on sustainable FM in developed countries in order to identify ways by which Nigerian FM professionals can adopt sustainable ways in the management of commercial buildings to achieve sustainability. The study also reviews existing literature on sustainable FM in Nigeria, so as to determine the extent of sustainable FM in Nigeria. An in-depth study of building assessment standards used in assessing a building's sustainable qualities was carried out, namely; the Building Research Establishment Environmental Assessment Method International New Construction (BREEAM-NC) UK, the Leadership in Energy \& Environmental Design for New Construction (LEED-NC) US, the International Standard Organisation (ISO) Sustainability in Building Construction and the British Standards (BS) Building Regulation PD 6501: Part 3: 1985. The SB constituents stated by each document were identified and compared to each other, in order to produce a concerted list of SB constituents. The concerted list revealed FM functions in 7 of the 10 major categories in relation to SB constituents and these include: Management, Health and Wellbeing, Energy, Water, Materials, Waste Management and Pollution. The findings reveal FM functions lacking in 3 areas of SB constituents and these include Transport, Land use and Ecology, and Innovation.

\section{Sustainable FM Practice in Developed Countries}

Facilities management in the United States has been established for over 30 years [14] and the International Facility Management Association (IFMA) is the world's largest and most widely recognized international association for facilities management professionals, supporting more than 23,000 members in 85 countries [15]. The FM market spread to Europe with the establishment of Euro FM in 1990 and the British Institute of Facilities Management (BIFM) in 1993 [16]. In the UK, FM is one of the fastest growing professions with a market worth of $£ 106.3$ billion and an anticipated annual growth of between $2 \%$ and $3 \%$ up to the year 2012 [17, 16].

Developed countries, particularly in Europe, have applied research focus to sustainable FM, although this is arguably still in its infancy. A case study in Finland showed that relatively light changes to FM service processes achieved extensive environmental benefits. In the case study building, they found that FM had direct or indirect (operational) influence on $82 \%$ of the green building certification (LEED) points achieved by the building [18]. However, even in developed countries, it seems that action towards sustainable facilities management is, at times, minimal. The term sustainable FM is unknown in Denmark but there may be greater awareness in the UK and other countries [19].

Facilities managers have a great role to play in advancing the sustainability agenda in the built environment through the practice of sustainable FM [20]. In the UK, the concept of sustainable FM has developed and grown in parallel with the all-embracing theory of sustainable development and the growing appreciation for climate change [18]. According to the study carried out by Elmualim (2008) facilities managers are now aligning their practice with the sustainability agenda along its three strands, economic, environmental and social [17]. However, they are constrained by time, lack of knowledge of the basic information necessary to implement sustainability policies and lack of senior management commitment to the sustainability agenda.

The main driver for sustainable FM in the UK is the formulation of legislation [18]. These pieces of legislation, make organisations conform to stipulated regulations and, in the process, drive the compliance of sustainable practices by facilities managers [19]. These laws incorporate sustainable policies that involve waste management, recycling, energy management, carbon footprint and health and safety [16].

In other developed countries, such as Japan, New Zealand, Hong Kong, Singapore and South Africa, FM has been successfully developed and established. It is recognised in these countries as an activity that can achieve more effective management of buildings, its services and associated workforce, in support of the strategic objectives of an organisation [20]. FM in Australia is one of the fast growing industries with an annual turnover of more than AUD\$60 billion [16].

\section{Sustainable FM in Nigeria}

In developing countries such as Malaysia, the development of FM started in the second half of the 1990s. Now Malaysia has put great focus and emphasis on the development of FM particularly in the public sector [21]. In Uganda, a study was carried out in order to project the growth of FM, which concluded that the FM industry in Uganda, though not officially recognised, exists in a capacity to grow steadily in line with the economy [22].

Sustainability in terms of environmental impact of various industries, especially the oil and petrochemical industry in 
Nigeria, has been well documented, [23-26]. However, sustainability in FM, in the country is yet to be embraced, as its growth has been slow, awareness is low and also there is little literature on the subject [27]. Literature that is available tends to focus on environmental issues in sustainability [28, 27], with little focus on the economic and social aspects. Sustainable FM in the management of public buildings in Nigeria and the development of a sustainable approach to corporate FM in Nigeria are existing literature on sustainable FM [27, 29]. [27] emphasised environmental sustainability in their study involving the use of questionnaires and interviews of FM professionals, regarding key themes including environmental awareness, performance of ecologically sustainable development activities and strategic management. Their results showed that FM only minimally addresses sustainability in Nigeria.

A comparative study of sustainable FM in the UK and Nigeria was carried out and it was found that the top three barriers to sustainable practice in Nigeria are lack of regulations or legislation; lack of sustainable policies and lack of awareness [9]. They proposed a framework for embedding sustainable FM in public buildings in Nigeria, based on six phases: (1) public awareness; (2) training and education; (3) creating legislation; (4) public organisations developing written sustainability policies; (5) incorporating sustainable practices in the management of public buildings and; (6) enforcing regulations/legislation.

A study was also carried out on assessing the level of commitment and barriers to sustainable FM practice by facilities managers within corporate organisations in Nigeria. This study revealed the three main barriers to sustainable FM practice. These are lack of training and tools, lack of relevant laws and regulation, and lack of knowledge and awareness. The study also identified the commitment of senior management personnel, as a major driver to the course of sustainable FM within organisations in Nigeria [29]. A similar study on sustainable FM was carried out in relation to the management of solid waste in the Nigerian built environment with particular emphasis on the healthcare facilities [30]. Nevertheless, there remains the urgent need to investigate barriers of sustainable FM practice in the management of commercial buildings in Nigeria. Commercial buildings, being the economic powerhouse of the nation, serving the whole of the country in respect of imports and locally manufactured goods; contributing more than $70 \%$ of the national economic output [31].

\section{Conclusion}

Though action towards sustainable FM practice in the developed countries is at times minimal, FM practitioners in these countries are achieving sustainable FM in relation to $\mathrm{SB}$. They do this by carrying out their functions in relation to SB constituents. Barriers to sustainable FM within corporate organisations in Nigeria have been identified; however, there remains the need to identify barriers to sustainable FM practice in the management of commercial buildings. The extent of sustainable FM in commercial buildings in Nigeria has not yet been determined. However, the findings so far, identify commitment of senior management personnel, as a major driver to the course of sustainable FM. This study is a work in progress and therefore, continuous effort will be made to determine the extent of sustainable practices in the management of commercial buildings and identify barriers to sustainable FM in commercial buildings in Nigeria. However, there remains the need for them to incorporate sustainable practices in the areas of Transport, Land use and Ecology, and Innovation in relations to SB.

\section{References}

[1] WCED (1987). "Report of the World Commission on Environment and Development: Our Common Future", Document A/42/427, WCED. Available at: http://www.undocuments.net/wced-ocf.htm (Accessed 24 February 2014).

[2] Brandon, P. and Lombardi, P. (2005). Evaluating Sustainable Development. Blackwell Science, UK.

[3] EPA (2016). What is sustainability. Viewed from: https://www.epa.gov/sustainability/learn-aboutsustainability\#what. Accessed on 30/11/2017.

[4] Alnaser. N. W., R. Flanagan, Alnaser W. E. (2008). 'Potential of making - over to sustainable buildings in the Kingdom of Bahrain'. Energy and Buildings, 40, 1304-1323.

[5] Mora. R., Bitsuamlak. G. and Horvat. M. (2011). Integrated life-cycle design of building enclosures. Building and Environment, 46, 1469-1479.

[6] Hafner, A. and Schäfer, S. (2017). Comparative LCA study of different timber and mineral buildings and calculation method for substitution factors on building level. Journal of Cleaner Production, 167, 630-642.

[7] Lam, E. W. M, Chan, A. P. C, and Chan, D. W. M. (2010). "Benchmarking success of building maintenance projects". Facilities, 28, No. 5/6, pp. 290-305.

[8] Wood (2006). The role of existing buildings in the sustainability agenda. Facilities, 24(1-2): 61-67.

[9] Iyagba, R. O. A. (2005). The Menace of Sick Buildings: A Challenge to all for its Prevention and Treatment. Nigeria: University of Lagos Press.

[10] Olarewaju. S. B. O and Anifowose. O. S. (2015). The Challenges of Building Maintenance in Nigeria: (A Case Study of Ekiti State). European Journal of Educational and Development Psychology, 3, 2, 30-39.

[11] Abigo. A., Madgwick. D., Gidado. K. and Okonji. S. (2012). Embedding Sustainable Facilities Management in the Management of Public Buildings in Nigeria. EPPM 2012, University of Brighton, Brighton, UK, 10-11 September 2012. Viewed http://www.ppml.url.tw/EPPM/conferences/2012/downioad/S ESSON5_B/35\%20E139.pdf [Accessed 26 January 2013].

[12] Odediran. S., Opatunji. O. and Eghenure. F. (2012). Maintenance of Residential Buildings: Users' Practices in Nigeria. Journal of Emerging Trends in Economics and Management Sciences (JETEMS), 3, 3, 261-265. 
[13] Ojara, E. S. (2013). The Challenges of Housing Maintenance in Nigeria. Unpublished HND Project, Department of Building Technology, The Federal Polytechnic Ado Ekiti, Nigeria.

[14] Wiggins, J. M. (2010). Facilities Manager's Desk Reference. Wiley-Blackwell, West Sussex, UK.

[15] IFMA (n.d.), "International Facility Management Association: Definition of Facility Management", Viewed from: http://www.ifma.org/about/aboutifma/history\#sthash.UAeyxW1Y.dpuf. Accessed on 27/10/2013.

[16] Shah. S. (2007). Sustainable Practice for the Facilities Manager. Blackwell Publishing, Oxford UK.

[17] Elmualim, A. A., Czwakiel, A., Valle, C. R., Ludlow, G. and Shah, S. (2008). Barriers for implementing sustainable facilities management. In: World sustainable building conference, 21-25, Melbourne, Australia.

[18] Aaltonen, A., Määttänen, E., Kyrö, R., Sarasoja, A. (2013), "Facilities management driving green building certification: a case from Finland", Facilities, 31, 7/8, pp. 328-342.

[19] Nielsen, S. B. (2012), "Claims of sustainable FM: Exploring current practices", Jensen, P. A., Nielsen, S. B. (Eds.), Facilities management research in the Nordic countries: Past, present and future, Polyteknisk Forlag, Lyngby, 121-132.

[20] Elmualim. A., Valle. R. and Kwawu. W. (2012). Discerning policy and drivers for sustainable facilities management practice. Journal of Sustainable Built Environment, 1, 16-25.

[21] Kamaruzzaman. S. N. and Zawawi. E. A. (2010). Development of facilities management in Malaysia. Journal of Facilities Management, 8, 1, 75-81.

[22] Natukunda, C. M., Pitt, M. and Nabil, A. (2013). Understanding the Outsourcing of Facilities Management Services in Uganda. Journal of Corporate Real Estate, 15, 2, $150-158$.
[23] Odeyemi. O and Ogunseitan. A. O. (1985). Petroleum Industry and its Pollution Potential in Nigeria, Oil \& Petrochemical Pollution, 2, 223-229.

[24] Olokesusi. F. (1992). Environmental Impact Assessment in Nigeria; Current Situation and Directions for the Future. Journal of Environmental Management, 35, 163-171.

[25] Osuji. L. C., Onojake. C. M. (2006). Field reconnaissance and estimation of petroleum hydrocarbon and heavy metal contents of soils affected by the Ebocha- 8 oil spillage in Niger Delta, Nigeria. Journal of Environmental Management 79, 133-139.

[26] Agbalagba. E. O, Avwiri. G. O. and Ononugbo. C. P. (2012). Activity concentration and radiological impact assessment of ${ }^{226} \mathrm{Ra},{ }^{228} \mathrm{Ra}$ and ${ }^{40} \mathrm{~K}$ in drinking waters from (OML) 30, 58 and 61 oil fields and host communities in Niger Delta region of Nigeria Journal of Environmental Radioactivity, 1- 4.

[27] Adewunmi. Y., Omirin. M., and Koleoso. H. (2012). "Developing a sustainable approach to corporate FM in Nigeria". Facilities, 30, 9/10, 350-373.

[28] Kadiri, K. O. (2006), "Planning sustainable and livable cities in Nigeria", Research Journal of Social Sciences, 1, 1, pp. 4050 .

[29] Ikediashi, D. I., Ogunlana, S. O., Oladokun, M. G. and Adewuyi, T. (2012). Assessing the level of commitment and barriers to sustainable facilities management practice: A case of Nigeria. Original Research Article. International Journal of Sustainable Built Environment, 1, 2, 167-176.

[30] Esara, E. E. and Okon, B. B. (2016). Evaluation of Solid Waste towards Sustainable Facilities Management. World Journal of Environmental Engineering, 4, 1, 19-22.

[31] Research Unit (2011) Alitheia Capital http://www.thealitheia.com/newsletters/Alitheia\%20Capital\% 20REInsight $\% 20-\% 20$ October $\% 202011$.pdf. Accessed on $22 / 2 / 13$ 